\title{
Immunosuppressors and immunomodulators in Neurology - Part I: a guide for management of patients under immunotherapy
}

\author{
Imunossupressores e imunomoduladores em Neurologia - Parte I: um guia para o manejo \\ de pacientes em imunoterapia
}

Fabiano Ferreira ABRANTES', Marianna Pinheiro Moraes de MORAES', José Marcos Vieira de Albuquerque FILHO', Jéssica Monique Dias ALENCAR', Alexandre Bussinger LOPES', Wladimir Bocca Vieira de Rezende PINTO', Paulo Victor Sgobbi de SOUZA', Enedina Maria Lobato de OLIVEIRA', Acary de Souza Bulle de OLIVEIRA', José Luiz PEDROSO'1, Orlando Graziani Povoas BARSOTTINI'

\begin{abstract}
For patients with autoimmune diseases, the risks and benefits of immunosuppressive or immunomodulatory treatment are a matter of continual concern. Knowledge of the follow-up routine for each drug is crucial, in order to attain better outcomes and avoid new disease activity or occurrence of adverse effects. To achieve control of autoimmune diseases, immunosuppressive and immunomodulatory drugs act on different pathways of the immune response. Knowledge of the mechanisms of action of these drugs and their recommended doses, adverse reactions and risks of infection and malignancy is essential for safe treatment. Each drug has a specific safety profile, and management should be adapted for different circumstances during the treatment. Primary prophylaxis for opportunistic infections and vaccination are indispensable steps during the treatment plan, given that these prevent potential severe infectious complications. General neurologists frequently prescribe immunosuppressive and immunomodulatory drugs, and awareness of the characteristics of each drug is crucial for treatment success. Implementation of a routine before, during and after use of these drugs avoids treatment-related complications and enables superior disease control.
\end{abstract}

Keywords: Immunosuppressive Agents; Immunologic Factors; Adrenal Cortex Hormones; Multiple Sclerosis; Autoimmune Diseases; Neurology.

\begin{abstract}
RESUMO
Pacientes com doenças autoimunes exigem uma constante preocupação com os riscos e benefícios do tratamento imunossupressor ou imunomodulador. O conhecimento das rotinas no uso de cada uma dessas drogas é fundamental para o bom desfecho clínico, evitando a piora da doença ou efeitos colaterais. As drogas imunossupressoras e imunomoduladoras agem em diferentes pontos da resposta imunológica a fim de controlar a doença para qual são indicadas. O conhecimento do mecanismo de ação, principais posologias, efeitos adversos e os riscos de infecções e neoplasias relacionadas ao uso dessas medicações são fundamentais para um tratamento seguro. Cada uma delas apresenta um perfil específico de complicações e o manejo deve ser individualizado em diferentes cenários ao longo do seguimento do paciente. $O$ uso de medicações para profilaxia primária de infecções e a vacinação são pontos essenciais no planejamento do tratamento, prevenindo potenciais complicações infecciosas ao longo do acompanhamento. $\mathrm{O}$ uso de imunossupressores e imunomoduladores é uma frequente realidade no dia-a-dia do neurologista, e o conhecimento das características de cada droga é crucial para o sucesso do tratamento. A realização de uma rotina antes, durante e depois do uso dessas medicações evita complicações relacionadas com o tratamento e alcança um melhor controle da doença.
\end{abstract}

Palavras-chave: Imunossupressores; Fatores Imunológicos; Corticosteroides; Esclerose Múltipla; Doenças Autoimunes; Neurologia.

\footnotetext{
${ }^{1}$ Universidade Federal de São Paulo, Departamento de Neurologia, Divisão de Neurologia Geral, São Paulo SP, Brazil.

FFA (D) https://orcid.org/0000-0002-3813-5993; MPMM (D) https://orcid.org/0000-0003-1273-9083; JMVAF (D) https://orcid.org/0000-0002-4533-2637; JMDA (iD) https://orcid.org/0000-0002-6354-4043;ABL (ID) https://orcid.org/0000-0001-5466-2155; WBVRP (iD https://orcid.org/0000-0002-0150-525X; PVSS (iD https://orcid.org/0000-0002-7416-7108; EMLO (iD https://orcid.org/0000-0002-4939-7200; ASBO (i) https://orcid.org/0000-0002-6986-4937; JLP (D) https://orcid.org/0000-0002-1672-8894;0GPB (D) https://orcid.org/0000-0002-0107-0831

Correspondence: Fabiano Ferreira Abrantes; Email: fabianofabrantes@hotmail.com.

Conflict of interest: There is no conflict of interest to declare.

Authors' contributions: FFA, MPMM, MVAF, OGB: conception, organization, and execution of the article project, writing, review, and critique of the first draft; JMDA, ABL, WBVRP, PVSS: execution of article project, review and critique of the manuscript; EMLO, ABSO: execution of article project, writing, review and critique of the manuscript; JLP: conception and execution of article project, writing, review and critique of the manuscript.

Received on January 05, 2020; Received in its final form on March 01, 2021; Accepted on March 12, 2021.
} 


\section{INTRODUCTION}

Significant developments within Immunology over the last decades have led to marked improvement in diagnosis and management of autoimmune disorders. A close relationship between Neurology and Immunology has been demonstrated by the large number of neurological disorders for which the pathophysiological explanation relates to immune-mediated mechanisms. Discoveries of new autoantibodies and new therapies have been increasing.

Considering all the developments at the interface of Neurology and Immunology, Autoimmune Neurology has been emerging as a new subspecialty ${ }^{1}$. In order to improve knowledge of and care for patients with autoimmune and demyelinating disorders, there is a large need for updates on management of these disorders. In line with this, drug management of autoimmune disorders requires understanding of accurate drug dosing, infusion schedules and the most suitable infection screening and follow-up.

We searched the PubMed and Scientific Electronic Library Online (SciELO) databases for published studies in Portuguese and English over the period 1990-2020. Through the search process, articles that described drug pharmacology, administration schemes, adverse effects and other safety issues were included. Articles and guidelines describing the major points relating to opportunistic infections and vaccination in patients under immunosuppression or immunomodulation were also included. The aim of this review of the literature was to provide a practical approach and guidance for general neurologists with regard to drug management for patients with different forms of autoimmune disorders that affect the nervous system.

\section{IMMUNOSUPPRESSIVE AND IMMUNOMODULATORY DRUGS}

Several types of immunosuppressive drugs are commonly used for patients with immune-mediated neurological disorders, and the most commonly used types within daily practice are discussed in the following topics and are summarized in Table 1.

\section{CORTICOSTEROIDS}

Corticosteroids are synthetic hormones that mimic the action of endogenous cortisone and modify metabolism and immune function through protein expression at DNA level. Also, corticosteroids reduce inflammatory responses and decrease lymphocyte, eosinophil and basophil counts ${ }^{2}$.

Prednisone is four times as potent as hydrocortisone. The usual dose of prednisone for immunosuppressive effects is 30 mg per day ${ }^{3}$. Other corticosteroids include dexamethasone, methylprednisolone and deflazacort. Table 2 summarizes the relative activity and length of action of different corticosteroids.

Corticosteroids are used for a variety of different neurological conditions, and not only autoimmune disorders: inflammatory processes relating to infections (e.g., tuberculosis or bacterial meningitis), primary refractory headaches (e.g., cluster headache), Duchenne muscular dystrophy and autoimmune or autoinflammatory diseases (e.g. Behçet's syndrome, Still's disease, sarcoidosis, multiple sclerosis relapses, neuromyelitis optica spectrum disorder [NMOSD] relapses, acute disseminated encephalomyelitis [ADEM], etc.).

Side effects relating to use of corticosteroids are common, and include insomnia and mood changes (euphoria); increased risk of sepsis; venous thromboembolism; bone fractures; obesity; glucose intolerance; diabetes; myopathy; osteoporosis; peptic ulcer; skin lesions; and infections ${ }^{4,5}$.

Pulse therapy is defined as treatment with doses higher than $250 \mathrm{mg}$ of prednisone or its equivalent ${ }^{6}$. Methylprednisolone is more widely used than prednisone for pulse therapy because of its lower mineralocorticoid activity. Pulse therapy with dexamethasone has shown similar results in patients with MS and optic neuritis? The usual dose of methylprednisolone is $1 \mathrm{~g}$ administered as an infusion diluted with $0.9 \%$ saline solution over 1-3 hours (to avoid hemodynamic instability) for 3 to 5 days. Before starting to administer pulse therapy, it is recommended that an evaluation should be conducted through routine laboratory tests (glucose, urea, creatinine and blood count), with prophylaxis for disseminated strongyloidiasis using antiparasitic drugs (e.g. ivermectin at $200 \mathrm{mcg} / \mathrm{kg}$ ). During drug infusion, vital sign monitoring is essential. Long-term corticosteroid use requires gradual tapering to avoid hypothalamicpituitary-adrenal axis suppression. For short-term use (less than 14 to 21 days) (including pulse therapy schemes), this tapering is not necessary ${ }^{8}$.

An initial metabolic profile, including screening for diabetes, dyslipidemia and vitamin D levels, should be assessed prior to starting administration of corticosteroid. Table 3 shows the basic monitoring during treatment with corticosteroids.

Corticosteroid-induced osteoporosis is usually multifactorial $^{5}$. Assessment of bone mineral density (BMD) is required before treatment and within one year. If $\mathrm{BMD}$ remains stable, this assessment can be repeated within 2-3 years ${ }^{3}$. Both calcium and vitamin D supplementation is recommended, in order to prevent BMD reduction'. The Fracture Risk Assessment Tool (FRAX) is a tool for evaluating patients' risk of fractures and it can help in deciding when to start treatment with common bisphosphonates ${ }^{10}$. Hip pain needs to be assessed by means of $\mathrm{x}$-rays and/or magnetic resonance imaging (MRI) because of the risk of spontaneous osteonecrosis. Patients on high-dose GLC should be evaluated for ophthalmological complications (e.g. glaucoma and cataracts) after an interval of 6-12 months.

One practical approach for corticosteroid dosage reduction to prevent serious side effects is to reduce the dose by $10-20 \%$ every 2-4 days. After reaching a dose of $5 \mathrm{mg}$ of prednisone or equivalent, the adrenal axis should be tested (serum ACTH and morning cortisol levels). If test results are normal, corticosteroids can be discontinued ${ }^{11}$. We recommend that patients with abnormal test results should be referred to an endocrinologist 


\begin{tabular}{|c|c|c|c|c|c|c|}
\hline 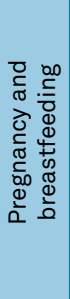 & 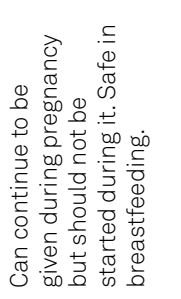 & 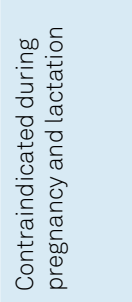 & 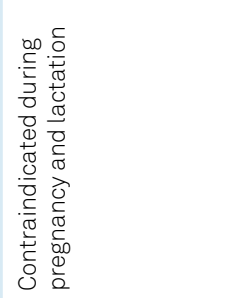 & 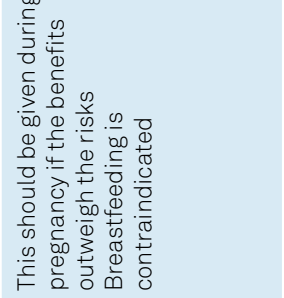 & 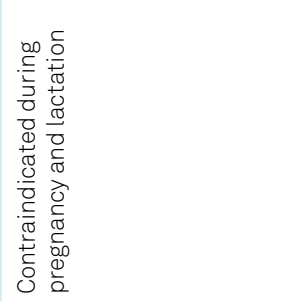 & 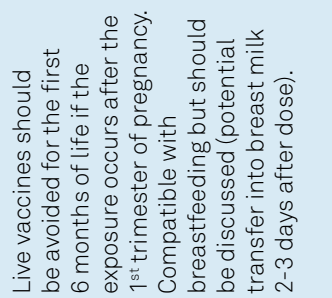 \\
\hline 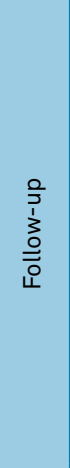 & 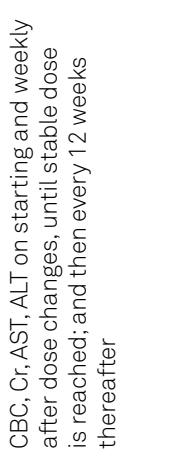 & 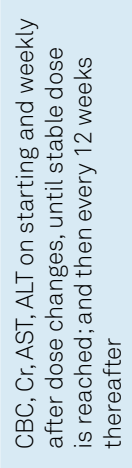 & 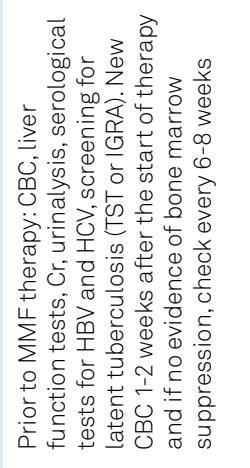 & 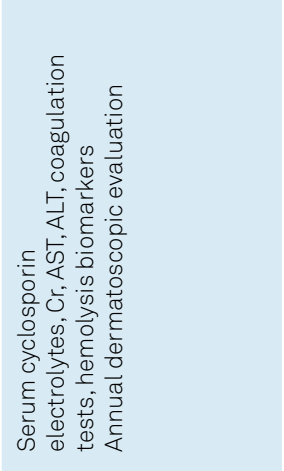 & 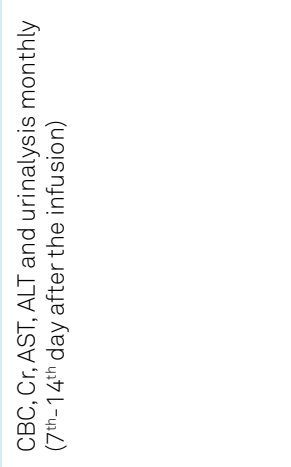 & 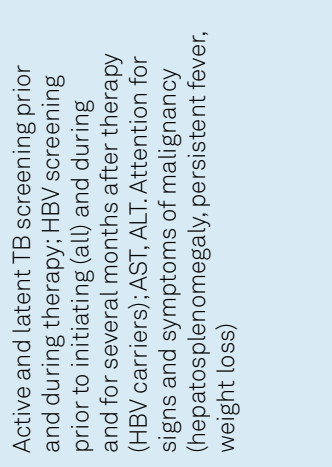 \\
\hline 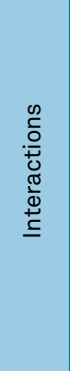 & 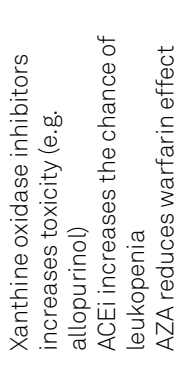 & 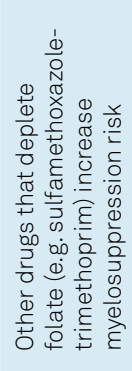 & 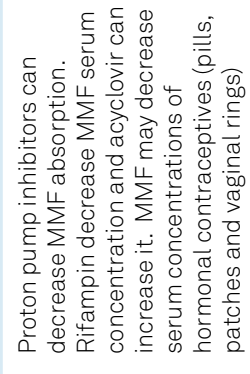 & 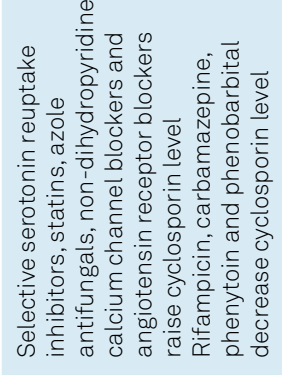 & 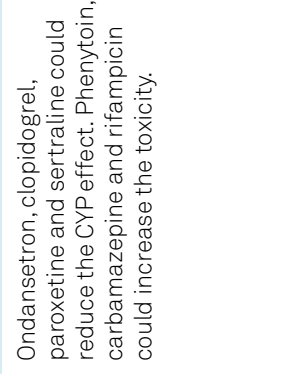 & 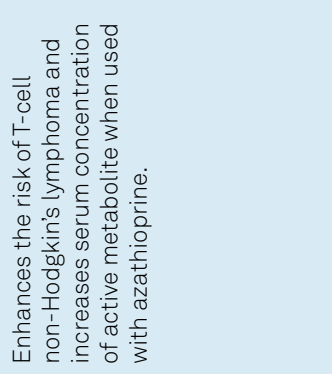 \\
\hline 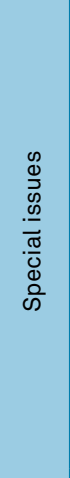 & 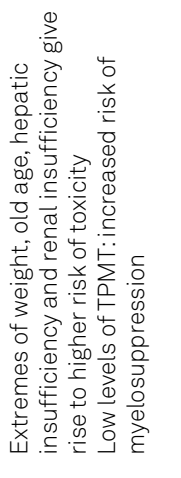 & 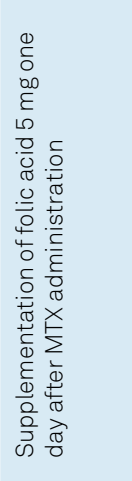 & 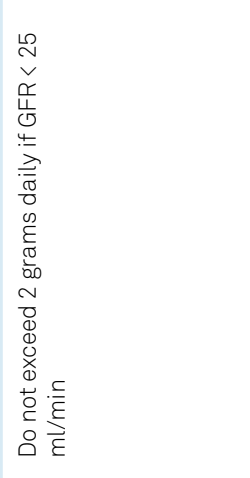 & 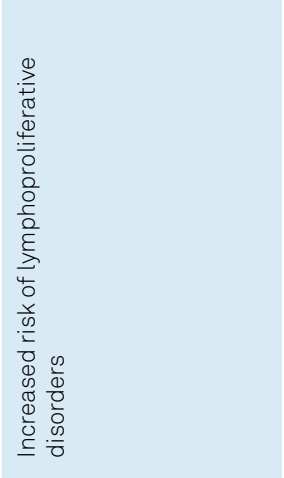 & 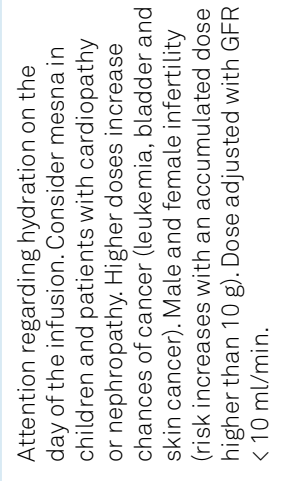 & 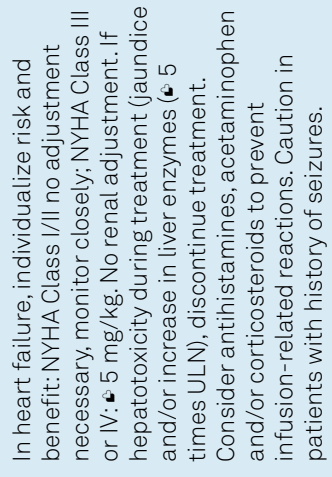 \\
\hline $\begin{array}{l}\stackrel{0}{\infty} \\
\stackrel{8}{\circ}\end{array}$ & 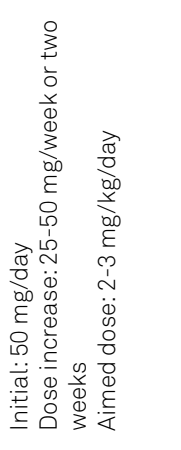 & 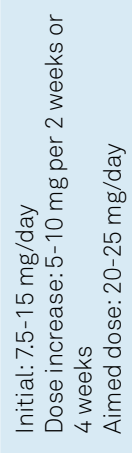 & 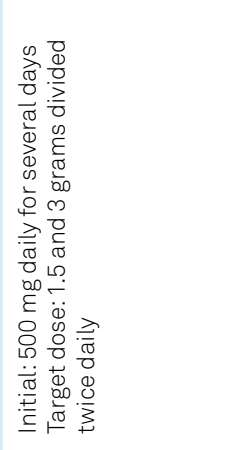 & 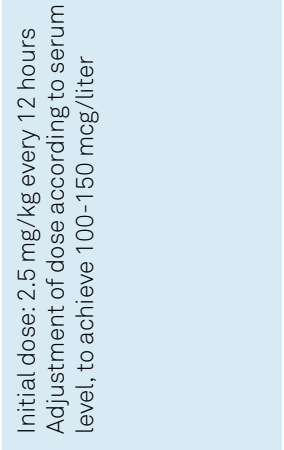 & 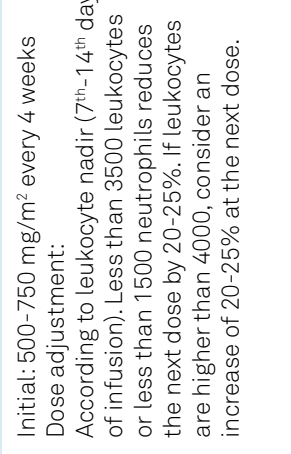 & 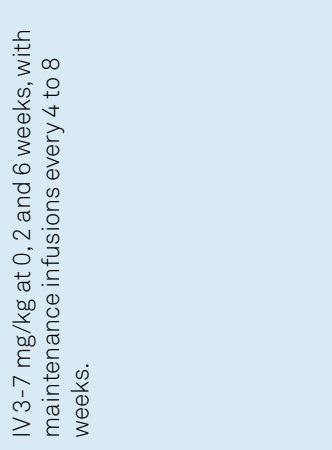 \\
\hline $\begin{array}{l}n^{\infty} \\
\stackrel{2}{ \pm}\end{array}$ & 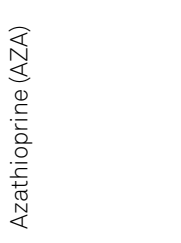 & 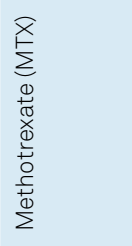 & 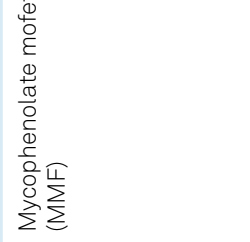 & $\begin{array}{l}\text { 등 } \\
\frac{0}{0} \\
\frac{0}{0} \\
\text { Oे }\end{array}$ & 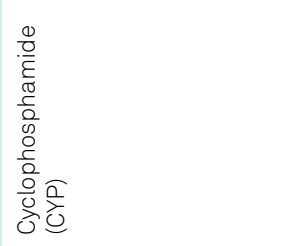 & 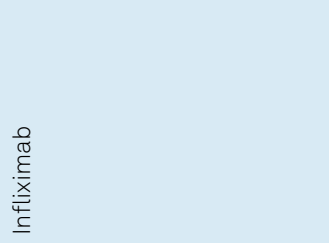 \\
\hline
\end{tabular}




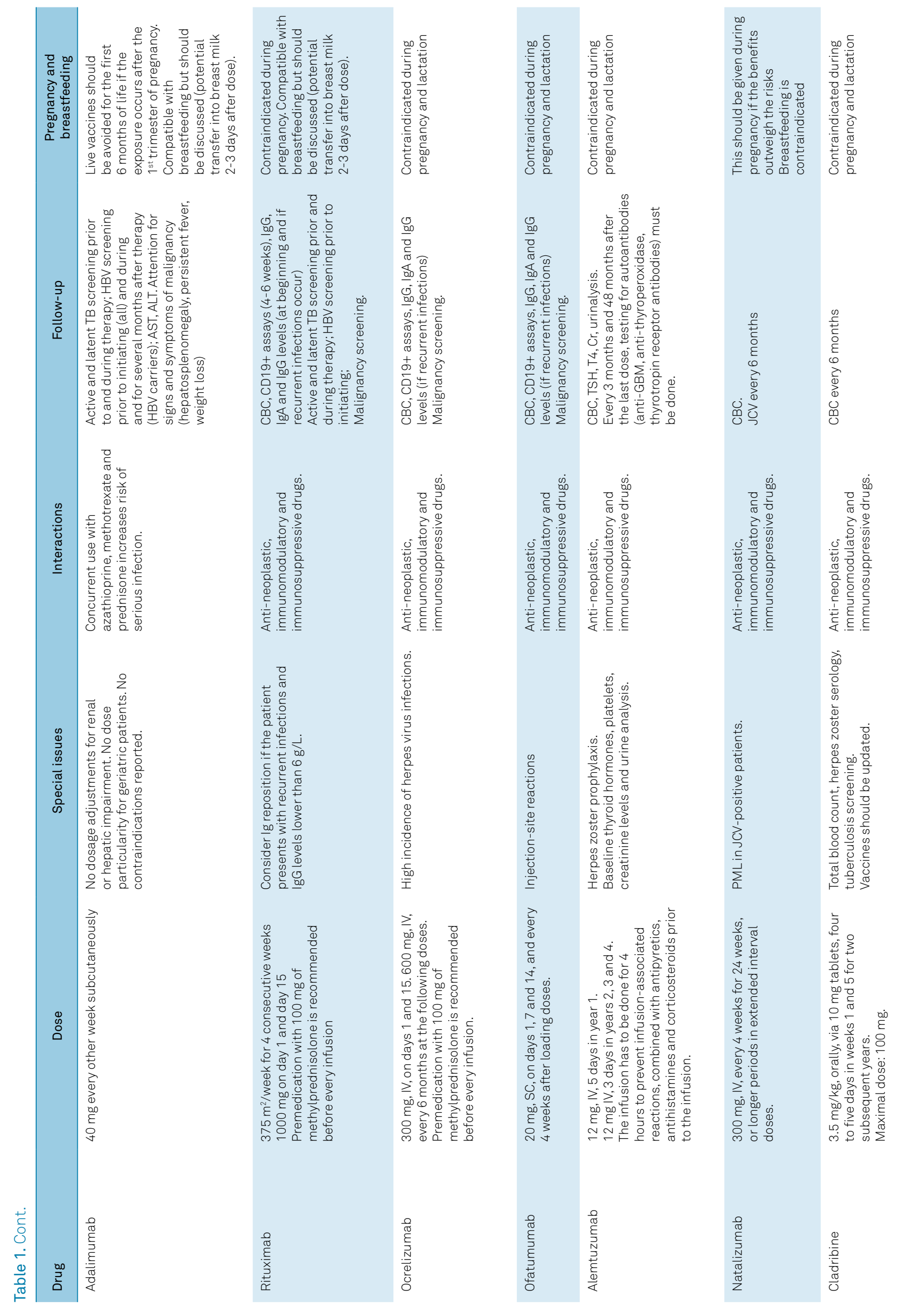




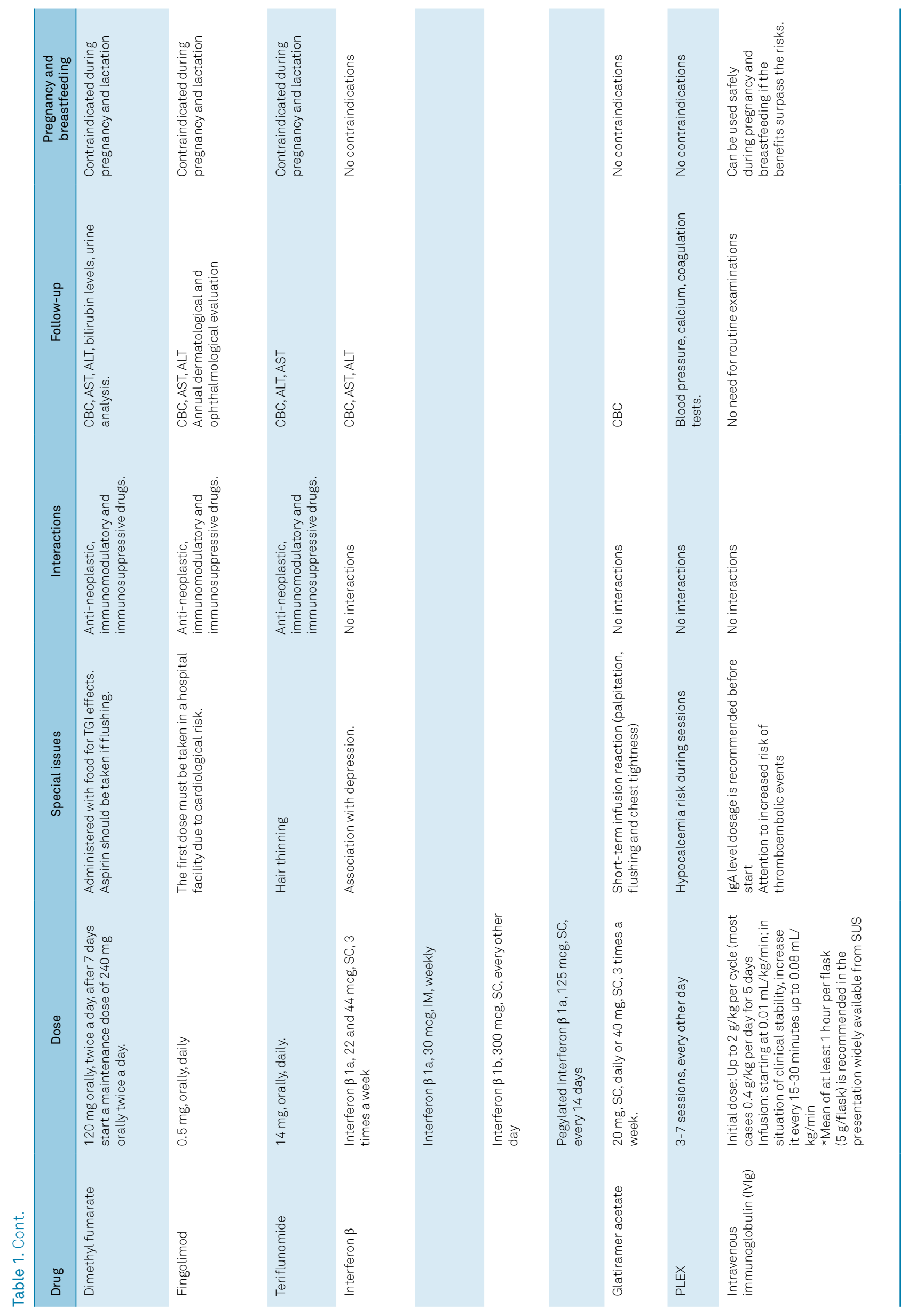



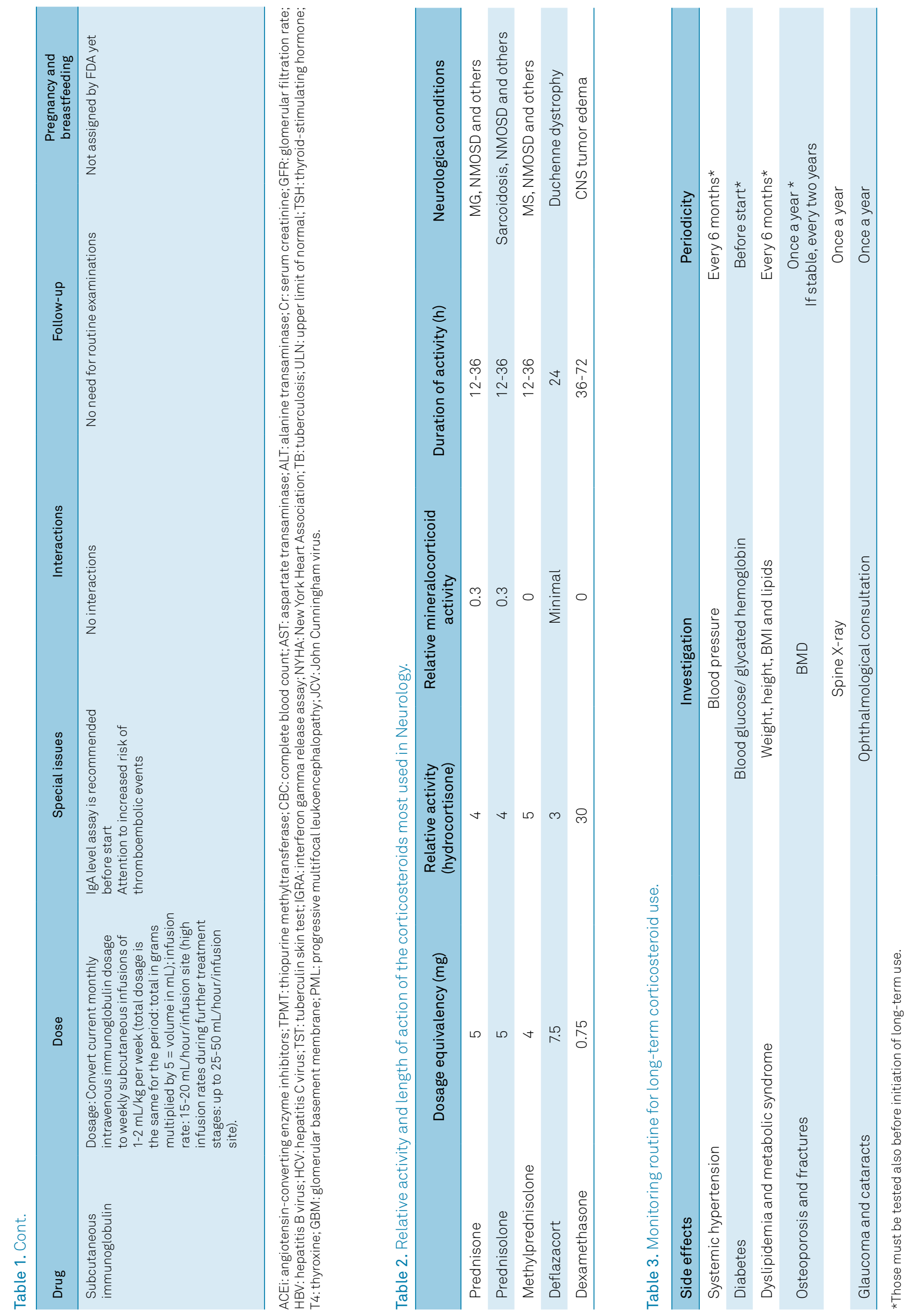
for evaluation of signs and symptoms of adrenal insufficiency and steroid withdrawal.

\section{AZATHIOPRINE}

Azathioprine belongs to the group of thiopurines. It undergoes metabolization to 6-mercaptopurine (6-MP), a metabolite that has immunosuppressive effects and inhibits purine synthesis, reduces leukocyte proliferation and impairs immune response ${ }^{12}$.

The main indications of azathioprine for neurological disease treatment are myasthenia gravis, NMOSD, primary central nervous system (CNS) vasculitis, immune-mediated myopathies, neuro-Behçet's disease (NBD) and chronic inflammatory demyelinating polyneuropathy (CIDP).

Hematological toxicity and the risk of myelosuppression are primary concerns associated with use of azathioprine, mostly related to low levels of thiopurine methyltransferase. Minor blood cell changes, including mild lymphopenia and increased mean corpuscular volume, may occur during treatment, but do not necessarily require drug discontinuation ${ }^{13}$. Other side effects include hepatotoxicity, nausea, vomiting and skin rash. Azathioprine has been associated with a low risk of malignancies ${ }^{13}$.

\section{METHOTREXATE}

Methotrexate (MTX) is a folic acid antagonist that inhibits purine and pyrimidine synthesis, thus affecting DNA and RNA synthesis ${ }^{14}$. It disrupts inflammatory and neoplastic cell division, reduces the levels of some cytokines (thereby leading to reactive oxygen species (ROS) accumulation in T-cells) and inhibits inflammatory transcription factors ${ }^{15}$.

MTX is widely used for managing several autoimmune disorders including sarcoidosis, immune-mediated myopathies and granulomatosis with polyangiitis (GPA). Patients on MTX may present incapacitating gastrointestinal side effects, mostly nausea and vomiting, and switching from oral to subcutaneous MTX may increase tolerance ${ }^{16}$. Other side effects include hepatotoxicity, stomatitis, pulmonary fibrosis, neurotoxicity (e.g., leukoencephalopathy), nodulosis, renal insufficiency and cytopenia ${ }^{17}$. Use of MTX has been associated with increased risk of lymphoproliferative disorders ${ }^{18}$.

\section{MYCOPHENOLATE MOFETIL}

Mycophenolate mofetil (MMF) is a drug with immunosuppressive properties that acts in purine synthesis and has antiproliferative effects on T- and B-lymphocytes, with depletion of lymphocytic and monocytic cells and inhibition of interleukin production $^{19}$. MMF is used in MG, NMOSD, autoimmune neuropathies and immune-mediated myopathies. It is also effective for treating systemic lupus erythematosus (SLE), vasculitis, rheumatoid arthritis and Takayasu arteritis ${ }^{20}$.

The side effects of MMF are usually mild, mostly consisting of gastrointestinal complaints (e.g. diarrhea, vomiting and mild abdominal pain), and mild lymphocytopenia can also occur. MMF increases the risk of lymphoproliferative disorders, especially in patients infected by Epstein-Barr virus ${ }^{21,22}$.

\section{CYCLOSPORINE (OR CYCLOSPORINE A)}

Cyclosporine reduces the cytosolic activity of calcineurin and proinflammatory cytokines (mainly IL-2) produced by T-lymphocytes. It is a corticosteroid-sparing drug used in management of inflammatory autoimmune neuromuscular disorders including generalized MG Class II-IV, dermatomyositis and idiopathic inflammatory myopathies and autoimmune neuropathies. It is usually reserved for refractory cases that have been treated with other agents (e.g. methotrexate, mycophenolate and azathioprine).

The common side effects of cyclosporine include arterial hypertension, hyperlipidemia, nephrotoxicity, hypomagnesemia, hyperkalemia and hypophosphatemia. Posterior reversible encephalopathy syndrome (PRES) induced by cyclosporine is rare.

\section{CYCLOPHOSPHAMIDE}

Cyclophosphamide is an alkylating agent that interferes in DNA synthesis and disrupts cell replication. Because of its effect, rapidly proliferating cells such as leukocytes are more susceptible to cyclophosphamide ${ }^{23}$.

Cyclophosphamide is used for treatment of neurological conditions including autoimmune encephalitis, primary CNS vasculitis, immune-mediated myopathies, neuropsychiatric SLE and neurological manifestations of systemic vasculitis.

There are three major safety concerns relating to this drug: hematological toxicity, infertility and hemorrhagic cystitis ${ }^{24}$. Cyclophosphamide may cause neutropenia, leukopenia and bone marrow suppression at high doses, generally occurring within 7 to 14 days of administration ${ }^{23}$. Female infertility and premature menopause are associated with cumulative doses and advanced age ${ }^{25}$. Hemorrhagic cystitis may occur due to exposure of the bladder to acrolein, a metabolite of cyclophosphamide ${ }^{26}$. Increased water ingestion and normotonic saline administration before and during infusion can increase urinary dilution and reduce exposure to acrolein, thus preventing occurrence of acrolein-induced hemorrhagic cystitis. Mesna can be used as an alternative agent, as it metabolizes acrolein to a less toxic compound and protects against hemorrhagic cystitis. Other side effects include alopecia, mucositis, nausea, vomiting, hyponatremia, nephrotoxicity, cardiac toxicity and hepatotoxicity ${ }^{24}$. 
Cyclophosphamide increases the risk of neoplasia, especially bladder cancer, and lymphoproliferative disorder ${ }^{27}$.

\section{ANTI-TUMOR NECROSIS FACTOR-}

Tumor necrosis factor- (TNF) is essential for macrophage and phagosome activation, differentiation of monocytes into macrophages, neutrophil and macrophage recruitment and granuloma formation and maintenance ${ }^{28}$. TNF inhibitors (antiTNF) are used to manage inflammatory conditions (e.g. rheumatoid arthritis, sarcoidosis and Behçet's disease).

Injection site reactions (ISR) are common side effects associated with anti-TNF therapies. They typically occur within the first month of treatment and last 3-5 days. Infusion reactions to infliximab are classified as acute (those that occur within 24 hours in $90 \%$ of infusions) or delayed (those that develop within 1-14 days of infusion), and they can be IgE-mediated (anaphylactic) including hypotension, bronchospasm, wheezing and urticaria or anaphylactoid (nonallergic) ${ }^{29,30}$. Neutropenia and infectious complications, including bacterial infections (particularly pneumonia), herpes zoster infection, tuberculosis and opportunistic infections, are adverse effects of this drug. Reactivation of hepatitis B virus can occur in chronic carriers. Although a causal relationship remains uncertain, this drug class should not be given to patients with demyelination ${ }^{31}$. Other adverse effects include heart failure, sarcoid-like pulmonary disease or fibrotic/interstitial pulmonary disease, hepatic involvement (acute liver failure, hepatitis and cholestasis) and cutaneous involvement (psoriasiform eczema, eczema, xerosis cutis, palmoplantar pustulosis and psoriasis $)^{32-34}$. Rare cases of autoimmune disorders, such as lupus-like syndrome and positive antinuclear antibody titers in patients who were negative at baseline, have been reported.

\section{ANTI-CD20}

Rituximab, ocrelizumab and ofatumumab are monoclonal antibodies that selectively target CD20, a cell surface antigen expressed in a broad range of B-cells. These drugs preferentially bind to CD20 on the cell surface of B-cells, which consequently leads to cell death through numerous mechanisms, including complement-dependent cytotoxicity, antibody-dependent cellular cytotoxicity and antibody-dependent cellular phagocytosis ${ }^{35}$.

Anti-CD20 therapies are used for managing several neurological disorders, including MS, NMOSD, MG, immunemediated myopathies, autoimmune encephalitis, CNS vasculitis and sarcoidosis. They are associated with high infection rates, especially of herpes virus infection, but most cases are mild. Patients on long-term anti-CD20 therapy are at risk of hypogammaglobulinemia with resultant higher risk of recurrent infections. They should be followed up with regular cancer screening examinations, and any suspicious lesions must be further assessed to rule out malignancies ${ }^{36}$.

\section{ALEMTUZUMAB}

Alemtuzumab is a humanized monoclonal antibody that is specific to CD52, a lymphocytic cell surface glycoprotein of unknown function. This drug causes profound depletion of peripheral lymphocytes and leads to long-lasting changes in adaptive immune response, and mild reduction of innate immune system cells (neutrophils and NK cells) $)^{37}$. It has been approved for treating patients with highly active MS.

Severe autoimmune-related adverse events have been reported from use of alemtuzumab. The most relevant adverse effects are thyroid diseases (17\% after three years of exposure), immune thrombocytopenia (ITP) (2.3\%) and nephropathies $(0.2 \%)^{38}$. Before treatment, baseline assessments should be performed, including thyroid hormone levels, platelet count, serum creatinine and urine analysis. A specialist should be consulted for advice on managing immune-related adverse event ${ }^{39}$.

Infections (commonly herpes simplex or zoster infection) may also occur. Prophylaxis is necessary until normal lymphocyte counts have been restored ${ }^{40}$.

\section{NATALIZUMAB}

Natalizumab is a humanized antibody that binds to a specific cell adhesion molecule called integrin. Integrins are expressed on the cell surface of all leukocytes, except neutrophils. This drug binds to integrin a $4 ß 1$ and a $4 ß 7$ subunits and blocks leukocytes from crossing the blood-brain barrier ${ }^{41}$.

Natalizumab is approved for treatment of patients with highly active relapsing-remitting MS (RRMS). Anti-JC virus (JCV) antibody serological status is used to determine treatment duration. Treatment can be discontinued after 24 infusions; however, new data has recently shown that treatment can be extended over 24 months with dosing intervals of 6 weeks ${ }^{42}$.

Progressive multifocal leukoencephalopathy (PML) is a major adverse event associated with continuous natalizumab therapy. The risk factors for PML include the number of infusions, anti-JCV status and index and prior use of immunosuppressants ${ }^{43}$.

Patients should be tested for anti-JCV antibody status before treatment is started and should be retested during treatment every 6 months to detect seroconversion or index augmentation $^{41}$. Nevertheless, regular 24-month treatment with natalizumab in patients testing positive for anti-JCV antibodies appears to be safe $\mathrm{s}^{43}$.

\section{CLADRIBINE}

Cladribine is an agent that causes profound lymphopenia due to cytotoxicity, particularly in lymphocytes. It disrupts cellular metabolism, inhibits DNA synthesis and repair and induces lymphocyte apoptosis ${ }^{44}$. Recently, an oral formulation of cladribine has been approved for treatment of highly active relapsing MS in Europe, USA and Brazil ${ }^{45}$. 
Cladribine has a good overall safety profile but, as expected, severe lymphopenia can occur ${ }^{46}$. However, lymphocyte counts tend to recover after discontinuation of treatment. The malignancy rate in cladribine-treated patients is almost the same as the rate in the overall population ${ }^{46}$.

\section{SPHINGOSINE 1-PHOSPHATE RECEPTOR MODULATORS}

Fingolimod and siponimod are sphingosine-1-phosphate (S1P) receptor modulators that acts as functional receptor antagonists. They inhibit the S1P1 receptor and block lymphocyte migration from lymph nodes to peripheral blood and through endothelial barriers such as the blood-brain barrier ${ }^{47}$. Fingolimod is used for treatment of RRMS.

$\mathrm{S} 1 \mathrm{P}$ receptors are present in different organs. It is thus recommended that cardiac and ophthalmological evaluations should be performed before treatment is started, in order to rule out preexisting conditions that may increase the risk of cardiovascular events and macular edema through continuous use of fingolimod ${ }^{47}$.

Patients should be given the first dose of fingolimod in a hospital setting and should be monitored for severe bradycardia and atrioventricular block over a six-hour period. Monitoring of lymphocyte counts should be performed, as fingolimod can cause lymphopenia and sometimes severe lymphopenia ( $\leq 200$ / $\mu \mathrm{L})$. Fingolimod-treated patients are at higher risk of herpes zoster infection and also other opportunistic infections such as TB and cryptococcosis ${ }^{48}$. Gradual withdrawal of fingolimod over a four-week period, in order to prevent rapid lymphocyte release and severe disease activation, has been suggested ${ }^{49}$.

\section{DIMETHYL FUMARATE}

Dimethyl fumarate (DMF) has been approved for treatment of RRMS. It has immunomodulatory and neuroprotective effects and acts by shifting the balance between pro-inflammatory and anti-inflammatory immune responses and altering the composition of lymphocyte subpopulations, thus resulting in induction of T-cell apoptosis, inhibition of activation of antigenpresenting cells and downregulation of vascular cell adhesion molecule expression in brain endothelium and of transmigration across the blood-brain barrier ${ }^{50}$.

Real-life data and data from pivotal studies have shown that adverse events are usually mild to moderate, including flushing, diarrhea and nausea, and seldom require drug discontinuation. Flushing can be managed with prophylactic use of aspirin and gastrointestinal events can be improved through food and initial-dose titration ${ }^{51}$.

DMF can cause severe and persistent lymphopenia, proteinuria and hematuria. Despite its safety, common infections such as nasopharyngitis and upper respiratory tract infections have been reported. PML has been described in a few older patients with prolonged lymphopenia $\left(0.5 \times 10^{9} / \mathrm{L}\right)^{52}$.

\section{TERIFLUNOMIDE}

Teriflunomide is an active metabolite of leflunomide with immunosuppressive activity that selectively inhibits dihydroorotate dehydrogenase (DHODH), a mitochondrial enzyme that is essential for the de novo pyrimidine nucleotide synthesis pathway and is expressed at high levels in proliferating lymphocytes. This drug reduces T-cell and B-cell activation and decreases their ability to cross the blood-brain barrier ${ }^{53}$.

Teriflunomide has been approved for treatment of RRMS and clinically isolated syndrome (CIS). It is a sustainable, safe drug. Common adverse events include hair thinning, nausea, diarrhea and alanine aminotransferase alterations ${ }^{54}$.

This drug is contraindicated for use in pregnant women and child-bearing women who are not using reliable contraception methods, since it can cause embryo-fetal developmental toxicity and malformations ${ }^{54}$. If pregnancy occurs during treatment, the patient must undergo an accelerated drug elimination procedure, with administration of cholestyramine or charcoal powder ${ }^{55}$.

\section{INTERFERON BETA}

Interferon beta (IFN $\beta$ ) acts on the immune system through a variety of mechanisms including inhibition of pro-inflammatory cytokines, inhibition of T-cell activation, stimulation of antiinflammatory cytokine production and restriction of leukocyte migration across the blood-brain barrier ${ }^{56}$.

IFN $\beta$-derived drugs are indicated for RRMS. The treatment has proven safety. Common adverse events include flulike symptoms, which can be managed with dose titration and symptomatic medication administered before injection. Lymphopenia and increased aminotransferase (AST and ALT) levels may occur and may eventually lead to drug withdrawal ${ }^{57}$. A previous history of depression is a known risk factor for developing new depressive episodes within the first six months of treatment and it is a contraindication for use of IFN $\beta^{58}$. IFN $\beta$ has been proved safe during pregnancy and lactation ${ }^{59}$.

\section{GLATIRAMER ACETATE}

Glatiramer acetate (GA) comprises four amino acids (L-glutamic acid, L-lysine, L-alanine and L-tyrosine) that form a synthetic analog of myelin basic protein (MBP). Its precise mechanism of action is not fully understood but involves immunomodulatory effects (Th1-Th2 shift and increased regulatory T-cells) and neuroprotective effects ${ }^{60}$.

GA is indicated for treating RRMS. Common adverse events associated with GA include mild injection site reactions (e.g. pain, erythema, edema and nodules) and mild immediate postinjection reactions (e.g. vasodilatation, chest pain, tachycardia and palpitation $)^{61}$. Patients on GA treatment are not at increased risk of malignancies or infections and do not require monitoring $^{62}$. It is a safe therapy during pregnancy and lactation ${ }^{63}$. 


\section{INTRAVENOUS IMMUNOGLOBULIN}

Intravenous immunoglobulin (IVIg) is a pool of functionally and structurally distinct human immunoglobulin G (IgG) from different individuals. It acts through various immune mechanisms to reduce autoreactive antibodies and causes indirect reduction of TNF- $\alpha$ and IL-10 and decreased macrophage activation ${ }^{64}$.

IVIg is indicated for treatment of acute inflammatory demyelinating polyneuropathy (Guillain-Barré syndrome) and its variants, except typical Miller-Fisher syndrome; multifocal motor neuropathy (MMN) with conduction block; small-fiber neuropathy with autoimmune dysautonomia; chronic inflammatory demyelinating polyneuropathy (CIDP); myasthenia gravis; relapsing myelin oligodendrocyte glycoprotein antibody-associated disease in both children and adults; immunemediated myopathies (dermatomyositis, immune-mediated necrotizing myopathy and overlapping syndromes) and dysphagia in sporadic inclusion body myopathy; idiopathic and paraneoplastic autoimmune encephalitis; and stiff-person syndrome and its variants.

Mild to moderate adverse reactions to IVIg therapy can occur. Patients who suffer from serum IgA deficiency are at higher risk, especially during the first administration of IVIg. These reactions include skin rash, headache, fever, thrombophlebitis, thromboembolic events, anaphylactic reactions, anaphylactoid reactions, aseptic meningitis, vestibular symptoms, myalgia, cramps, diarrhea, hypertensive crisis, hypotension, cardiac arrhythmias, chest pain, hemolytic anemia, transient neutropenia, acute renal failure, pseudohyponatremia and transfusion-related acute lung injury (TRALI). A slow infusion rate and pre-hydration with $500 \mathrm{~mL}$ of $0.9 \%$ saline solution for adults can minimize these reactions ${ }^{65}$.

\section{SUBCUTANEOUS IMMUNOGLOBULIN}

Subcutaneous immunoglobulin (SCIg) and IVIg have similar mechanisms of action and clinical indications. SCIg is indicated for treatment of patients with serious adverse effects from IVIg or when venous access is unavailable; and in situations of CIDP, MMN, immune-mediated myopathies and autoimmune MG (during acute exacerbations).

SCIg is well tolerated in general and safer than IVIg, but it can cause local granuloma-like reactions, fever, skin rash, cellulitis, anaphylaxis due to inadvertent vascular injection, skin eruptions, pruritus and joint pain ${ }^{65,66}$.

\section{THERAPEUTIC PLASMA EXCHANGE}

Therapeutic plasma exchange (TPE or PLEX) is a therapeutic procedure using an apheresis device in which the plasma is separated from whole blood, removed and replaced with a substitution fluid (albumin or saline). PLEX requires adequate venous access (a central venous catheter). It usually involves 3-7 sessions with time intervals of 24-48 $\mathrm{h}$ between sessions, and typically 1-1.5 plasma volumes are removed per procedure ${ }^{67}$.

PLEX is a well-established treatment for MG, Guillain-Barré syndrome, CIDP, paraproteinemic demyelinating polyneuropathies, chronic focal encephalitis (Rasmussen encephalitis), Lambert-Eaton myasthenic syndrome, MS (acute exacerbation) and NMOSD (during acute exacerbations).

Occurrences of adverse events in PLEX are associated with several factors including preexisting conditions. Severe symptoms are mostly associated with addition of infusion fluid or anticoagulants (citrate) during the procedure. Citrate can cause symptomatic hypocalcemia, and patients may develop allergic reactions due to the infusion fluid ${ }^{68}$. Hypotension, arrhythmias and tetany may occur; therefore, patient monitoring is required during the procedure ${ }^{69}$.

\section{RECOMMENDATIONS FOR VACCINATION AND PROPHYLAXIS FOR PATIENTS UNDERGOING TREATMENT WITH IMMUNOSUPPRESSIVE DRUGS}

Regular evaluation of immunization schedules is an essential part of consultations for immunosuppressed patients. Safety and immunogenicity are the major concerns regarding vaccination. The immunization schedule should be updated four weeks before immunosuppression is started ${ }^{70}$. When the therapy cannot be delayed, the minimum interval from vaccine dose to treatment start is two weeks ${ }^{71-73}$.

Live-agent vaccines (e.g. yellow fever, oral polio and measles-mumps-rubella) have higher risk of severe adverse effects in patients under immunosuppression. Patients under mild to moderate immunosuppression can be considered for live-agent vaccine if their clinical and epidemiological profile is favor$a_{b l e}{ }^{71}$. Patients with a controlled autoimmune disease who are at higher risk of becoming infected (e.g. through living in yellow fever endemic areas) might be considered to be candidates to receive the vaccine. Contacts of immunosuppressed patients should not receive oral polio vaccine due to the risk of viable virus transmission. Maternal exposure to biological agents during pregnancy is a contraindication for application of rotavirus vaccine and BCG vaccination until the child is six months of age $\mathrm{e}^{71}$. Table 4 summarizes a routine for immunization of patients before, during and after immunosuppression.

\section{OPPORTUNISTIC INFECTIONS, SCREENING AND PROPHYLAXIS FOR PATIENTS UNDERGOING TREATMENT WITH IMMUNOSUPPRESSIVE DRUGS}

Patients on immunosuppressive therapy are highly susceptible to opportunistic infections. Identification of risk factors, clinical and laboratory monitoring, vaccination and patient education are key to preventing opportunistic infections in these patients.

Corticosteroids have been associated with invasive fungal infections, especially Candida sp. and Pneumocystis jirovecii 
Table 4. Vaccination issues before, during and after immunosuppression.

\begin{tabular}{|c|c|c|}
\hline Vaccination pre-immunosuppression: & Vaccination on immunosuppression: & After immunosuppression: \\
\hline $\begin{array}{l}\text { Non-live vaccines should be administered at } \\
\text { least two weeks prior to treatment; } \\
\text { Live vaccines should be given at least one } \\
\text { month prior to treatment; } \\
\text { Pneumococcal vaccine should be given to all } \\
\text { immunosuppressed patients; } \\
\text { Influenza vaccine should be given yearly for } \\
\text { patient and household. }\end{array}$ & $\begin{array}{l}\text { Generally, no live vaccines should be given; } \\
\text { All patients should receive HPV vaccine } \\
\text { if age-appropriate and a yearly influenza } \\
\text { vaccine (inactivated); } \\
\text { Meningococcal vaccines should } \\
\text { be repeated every five years if } \\
\text { immunosuppression is ongoing. }\end{array}$ & $\begin{array}{l}\text { After } 4 \text { months off therapy, check } \\
\text { baseline serology (VZV, measles, } \\
\text { mumps, rubella, hepatitis A and B, } \\
\text { diphtheria, tetanus and } H \text {. influenzae } \\
\text { b), if antibodies are present, polio/ } \\
\text { pertussis vaccines do not need to be re- } \\
\text { administered; } \\
\text { If lymphocyte count > } 1,000 \text {, initiate re- } \\
\text { immunization schedule; } \\
\text { IVIg interferes with antibody response to } \\
\text { live vaccines. These should be delayed } \\
\text { until } 9 \text { months (if } 1 \mathrm{~g} / \mathrm{kg} / \text { dose given) or } \\
11 \text { months (if } 2 \mathrm{~g} / \mathrm{kg} / \text { dose given). }\end{array}$ \\
\hline
\end{tabular}

HPV: human papillomavirus; VZV: varicella-zoster virus.

(PJP). Administration of sulfamethoxazole-trimethoprim 2-3 times a week (or dapsone when a patient is allergic) is known to prevent PJP infection in patients with ANCA-positive vasculitis (especially granulomatosis with polyangiitis during induction treatment) and those receiving corticosteroids with other agents such as azathioprine, cyclophosphamide and methotrexate ${ }^{74}$.

Use of thiopurines, MTX and infliximab has been associated with increased risk of $C$. difficile-associated disease ${ }^{75}$. Vaccination is able to prevent pneumonia and meningitis caused by Streptococcus pneumoniae (revaccination is recommended because antibody levels decrease over time $)^{76}$.

All patients should be evaluated to determine the risk of latent or active TB (especially those on corticosteroids, cladribine, teriflunomide and anti-TNF) through tuberculin skin testing or interferon-gamma-release assays (IGRAs). A definitive diagnosis of latent $\mathrm{TB}$ is established through identifying risk factors and through positive screening tests, even without clinical or radiographic evidence of active TB. The European Crohn's and Colitis Organization (ECCO) guidelines recommend delaying anti-TNF therapy for TB patients for at least three weeks after starting chemoprophylaxis with isoniazid or rifampicin ${ }^{77}$.

Patients should be screened for hepatitis B virus (HBV) (HBsAg, anti-HBc and anti-HBs) before immunosuppression because of the risk of reactivation of HBV replication ${ }^{78}$. It is also recommended to test for HIV infection. Corticosteroids increase the CD4 population and decrease the HIV viral load, while AZA therapy is associated with increased viral replication $^{79}$. Varicella-zoster virus can cause encephalitis, pneumonia, hepatitis and death, particularly among older patients and those using anti-TNF, fingolimod and corticosteroids. Thus, active vaccination is recommended ${ }^{80}$. Over $90 \%$ of the world's population is infected with Epstein-Barr virus (EBV), and seropositivity increases with age ${ }^{81}$. AZA has been associated with EBV hepatitis, mucocutaneous ulcers and hemophagocytic syndrome, and IFX has been linked to severe complications or atypical presentations ${ }^{82}$. All patients should be vaccinated against human papillomavirus (HPV), and women require more frequent gynecological examinations and cervical screening ${ }^{83}$.

In conclusion, the follow-up for patients with autoimmune diseases is a complex task, and correct management of immunosuppressive or immunomodulatory drugs is crucial for ensuring better outcomes. Knowledge of doses, adverse effects and follow-up details for each drug used is essential for attaining a balance between the risks and benefits of immunosuppression. Vaccination, prophylaxis for infections and adverse effect screening are important issues to be considered before, during and after the treatment. This review may serve as a guide for general neurologists, to help in management of patients under treatment with immunosuppressive or immunomodulatory drugs.

\section{REFERENCES}

1. López-Chiriboga AS, Clardy SL. Emerging subspecialties in neurology: autoimmune neurology. Neurology. 2017 Sep 12;89(11):e129-33. https://doi.org/10.1212/WNL.0000000000004356

2. Hardy RS, Raza K, Cooper MS. Therapeutic glucocorticoids: mechanisms of actions in rheumatic diseases. Nat Rev Rheumatol. 2020 Mar;16(3):133-44. https://doi.org/10.1038/s41584-020-0371-y

Liu D, Ahmet A, Ward L, Krishnamoorty P, Mandelcorn ED, Leigh R, et al. A practical guide to the monitoring and management of the complications of systemic corticosteroid therapy. Allergy Asthma Clin Immunol. 2013 Aug 15;9(1):30. https://doi.org/10.1186/1710-14929-30
4. Waljee AK, Rogers MAM, Lin P, Singal AG, Stein JD, Marks RM, et al. Short term use of oral corticosteroids and related harms among adults in the United States: population based cohort study. BMJ. 2017 Apr 12;357:j1415. https://doi.org/10.1136/bmj.j1415

5. Stanbury RM, Graham EM. Systemic corticosteroid therapy-side effects and their management. Br J Ophthalmol. 1998 Jun 1;82(6):704-8. https://doi.org/10.1136/bjo.82.6.704

6. Buttgereit F, da Silva JAP, Boers M, Burmester G-R, Cutolo M, Jacobs $J$, et al. Standardised nomenclature for glucocorticoid dosages and glucocorticoid treatment regimens: current questions and tentative answers in rheumatology. Ann Rheum Dis. 2002 Aug 1;61(8):718-22. https://doi.org/10.1136/ard.61.8.718 
7. La Mantia L, Eoli M, Milanese C, Salmaggi A, Dufour A, Torri V. Doubleblind trial of dexamethasone versus methylprednisolone in multiple sclerosis acute relapses. Eur Neurol. 1994;34(4):199-203. https://doi. org/10.1159/000117038

8. Yasir M, Goyal A, Bansal P, Sonthalia S. Corticosteroid adverse effects. In: StatPearls [Internet]. Treasure Island (FL):StatPearls Publishing; 2021. Available from: http://www.ncbi.nlm.nih.gov/ pubmed/30285357

9. Homik J, Suarez-Almazor ME, Shea B, Cranney A, Wells G, Tugwell P. Calcium and vitamin D for corticosteroid-induced osteoporosis. Cochrane Database Syst Rev. 2000;1998(2):CD000952. https://doi. org/10.1002/14651858.CD000952

10. Pereira RMR, de Carvalho JF, Paula AP, Zerbini C, Domiciano DS, Gonçalves H, et al. Guidelines for the prevention and treatment of glucocorticoid-induced osteoporosis. Rev Bras Reumatol. 2012 Aug;52(4):580-93.

11. Alves C, Robazzi TCV, Mendonça M. Withdrawal from glucocorticosteroid therapy: clinical practice recommendations. J Pediatr (Rio J). 2008 May-Jun;84(3):192-202. https://doi.org/10.2223/ JPED.1773

12. Broen JCA, van Laar JM. Mycophenolate mofetil, azathioprine and tacrolimus: mechanisms in rheumatology. Nat Rev Rheumatol. 2020 Mar;16(3):167-78. https://doi.org/10.1038/s41584-020-0374-8

13. McWilliam M, Khan U. Azathioprine and the neurologist. Pract Neurol. 2020 Feb;20(1):69-74. https://doi.org/10.1136/ practneurol-2018-002161

14. Chan ESL, Cronstein BN. Mechanisms of action of methotrexate. Bull Hosp Joint Dis (2013). 2013;71 Suppl 1:S5-8.

15. Cronstein BN, Aune TM. Methotrexate and its mechanisms of action in inflammatory arthritis. Nat Rev Rheumatol. 2020 Mar;16(3):145-54. https://doi.org/10.1038/s41584-020-0373-9

16. Romão VC, Lima A, Bernardes M, Canhão H, Fonseca JE. Three decades of low-dose methotrexate in rheumatoid arthritis: can we predict toxicity? Immunol Res. 2014 Dec;60(2-3):289-310. https://doi. org/10.1007/s12026-014-8564-6

17. Bedoui Y, Guillot X, Sélambarom J, Guiraud P, Giry C, Jaffar-Bandjee $\mathrm{MC}$, et al. Methotrexate an old drug with new tricks. Int J Mol Sci. 2019 Oct 10;20(20):5023. https://doi.org/10.3390/ijms20205023

18. Wang W, Zhou H, Liu L. Side effects of methotrexate therapy for rheumatoid arthritis: a systematic review. Eur J Med Chem. 2018 Oct 5;158:502-16. https://doi.org/10.1016/j.ejmech.2018.09.027

19. Allison A. Mechanisms of action of mycophenolate mofetil. Lupus. 2005 Mar 1;14(3 Suppl 1):s2-8. https://doi. org/10.1191/0961203305LU21090A

20. Vermersch P, Stojkovic T, de Seze J. Mycophenolate mofetil and neurological diseases. Lupus. 2005;14(3 Suppl 1):s42-5. https://doi. org/10.1191/0961203305LU21170A

21. Rahman ANA, Tett SE, Staatz CE. Clinical pharmacokinetics and pharmacodynamics of mycophenolate in patients with autoimmune disease. Clin Pharmacokinet. 2013 May;52(5):303-31. https://doi. org/10.1007/s40262-013-0039-8

22. Lee A, Bridges LR, Lloyd M, Barker R, Wren DR, Galtrey CM. EpsteinBarr virus associated CNS lymphoproliferative disorder after longterm immunosuppression. Pract Neurol. 2020 Feb;20(1):83-6. https:// doi.org/10.1136/practneurol-2019-002356

23. Ahlmann M, Hempel G. The effect of cyclophosphamide on the immune system: implications for clinical cancer therapy. Cancer Chemother Pharmacol. 2016 Oct;78(4):661-71. https://doi. org/10.1007/s00280-016-3152-1

24. Teles KA, Medeiros-Souza P, Lima FAC, de Araújo BG, Lima RAC. Cyclophosphamide administration routine in autoimmune rheumatic diseases: a review. Rev Bras Reumatol Engl Ed. 2017 NovDec;57(6):596-604. https://doi.org/10.1016/j.rbre.2016.09.008

25. Khizroeva J, Nalli C, Bitsadze V, Lojacono A, Zatti S, Andreoli L, et al. Infertility in women with systemic autoimmune diseases. Best
Pract Res Clin Endocrinol Metab. 2019 Dec;33(6):101369. https://doi. org/10.1016/j.beem.2019.101369

26. Emadi A, Jones RJ, Brodsky RA. Cyclophosphamide and cancer: golden anniversary. Nat Rev Clin Oncol. 2009 Nov;6(11):638-47. https://doi.org/10.1038/nrclinonc.2009.146

27. van den Brand JAJG, van Dijk PR, Hofstra JM, Wetzels JFM. Cancer risk after cyclophosphamide treatment in idiopathic membranous nephropathy. Clin J Am Soc Nephrol. 2014 Jun 6;9(6):1066-73. https:// doi.org/10.2215/CJN.08880813

28. Roach DR, Bean AGD, Demangel C, France MP, Briscoe H, Britton WJ. TNF regulates chemokine induction essential for cell recruitment, granuloma formation, and clearance of mycobacterial infection. J Immunol. 2002 May 1;168(9):4620-7. https://doi.org/10.4049/ jimmunol.168.9.4620

29. Cheifetz A, Smedley M, Martin S, Reiter M, Leone G, Mayer L, et al. The incidence and management of infusion reactions to infliximab: a large center experience. Am J Gastroenterol. 2003 Jun;98(6):1315-24. https://doi.org/10.1111/j.1572-0241.2003.07457.x

30. Vultaggio A, Matucci A, Nencini F, Pratesi S, Parronchi P, Rossi O, et al. Anti-infliximab IgE and non-lgE antibodies and induction of infusionrelated severe anaphylactic reactions. Allergy. 2010 May;65(5):65761. https://doi.org/10.1111/j.1398-9995.2009.02280.x

31. Kemanetzoglou E, Andreadou E. CNS Demyelination with TNF-口 Blockers. Curr Neurol Neurosci Rep. 2017 Apr;17(4):36. https://doi. org/10.1007/s11910-017-0742-1

32. Solomon DH, Rassen JA, Kuriya B, Chen L, Harrold LR, Graham DJ, et al. Heart failure risk among patients with rheumatoid arthritis starting a TNF antagonist. Ann Rheum Dis. 2013 Nov;72(11):1813-8. https://doi.org/10.1136/annrheumdis-2012-202136

33. Khasnis AA, Calabrese LH. Tumor necrosis factor inhibitors and lung disease: a paradox of efficacy and risk. Semin Arthritis Rheum. 2010 Oct;40(2):147-63. https://doi.org/10.1016/j.semarthrit.2009.09.001

34. Lee H-H, Song I-H, Friedrich M, Gauliard A, Detert J, Röwert J, et al. Cutaneous side-effects in patients with rheumatic diseases during application of tumour necrosis factor-alpha antagonists. $\mathrm{Br}$ J Dermatol. 2007 Mar;156(3):486-91. https://doi.org/10.1111/j.13652133.2007.07682.x

35. Whittam DH, Tallantyre EC, Jolles S, Huda S, Moots RJ, Kim HJ, et al. Rituximab in neurological disease: principles, evidence and practice. Pract Neurol. 2019 Feb;19(1):5-20. https://doi.org/10.1136/ practneurol-2018-001899

36. Ellwardt E, Rolfes L, Klein J, Pape K, Ruck T, Wiendl H, et al. Ocrelizumab initiation in patients with MS: a multicenter observational study. Neurol Neuroimmunol Neuroinflamm. $2020 \mathrm{Apr}$ 9;7(4):e719. https://doi.org/10.1212/NXI.0000000000000719

37. Coles AJ, Twyman CL, Arnold DL, Cohen JA, Confavreux C, Fox EJ, et al. Alemtuzumab for patients with relapsing multiple sclerosis after disease-modifying therapy: a randomised controlled phase 3 trial. Lancet. 2012 Nov 24;380(9856):1829-39. https://doi.org/10.1016/ S0140-6736(12)61768-1

38. Devonshire V, Phillips R, Wass H, Da Roza G, Senior P. Monitoring and management of autoimmunity in multiple sclerosis patients treated with alemtuzumab: practical recommendations. J Neurol. 2018 Nov;265(11):2494-2505. https://doi.org/10.1007/s00415-018-8822-y

39. Berger T, Elovaara I, Fredrikson S, McGuigan C, Moiola L, Myhr K-M, et al. Alemtuzumab use in clinical practice: recommendations from European Multiple Sclerosis Experts. CNS Drugs. 2017 Jan;31(1):3350. https://doi.org/10.1007/s40263-016-0394-8

40. Wray S, Havrdova E, Snydman DR, Arnold DL, Cohen JA, Coles AJ, et al. Infection risk with alemtuzumab decreases over time: pooled analysis of 6-year data from the CAMMS223, CARE-MS I, and CAREMS II studies and the CAMMS03409 extension study. Mult Scler. 2019 Oct;25(12):1605-17. https://doi.org/10.1177/1352458518796675

41. Shirani A, Stüve O. Natalizumab for Multiple Sclerosis: a case in point for the impact of translational neuroimmunology. J Immunol. 2017 Feb 15;198(4):1381-6. https://doi.org/10.4049/jimmunol.1601358 
42. Ryerson LZ, Frohman TC, Foley J, Kister I, Weinstock-Guttman B, Tornatore $\mathrm{C}$, et al. Extended interval dosing of natalizumab in multiple sclerosis. J Neurol Neurosurg Psychiatry. 2016 Jul 14;87(8):885-9. https://doi.org/10.1136/jnnp-2015-312940

43. Schwab N, Schneider-Hohendorf T, Melzer N, Cutter G, Wiendl H. Natalizumab-associated PML: challenges with incidence, resulting risk, and risk stratification. Neurology. 2017 Mar 21;88(12):11971205. https://doi.org/10.1212/WNL.0000000000003739

44. Hermann R, Karlsson MO, Novakovic AM, Terranova N, Fluck M, Munafo A. The clinical pharmacology of cladribine tablets for the treatment of relapsing multiple sclerosis. Clin Pharmacokinet. 2019 Mar 5;58(3):283-97. https://doi.org/10.1007/s40262-018-0695-9

45. Giovannoni G, Comi G, Cook S, Rammohan K, Rieckmann P, Sørensenet PS, et al. A placebo-controlled trial of oral cladribine for relapsing multiple sclerosis. N Engl J Med. 2010 Feb 4;362(5):416-26. https://doi.org/10.1056/NEJMoa0902533

46. Cook S, Vermersch P, Comi G, Giovannoni G, Rammohan K, Rieckmann P, et al. Safety and tolerability of cladribine tablets in multiple sclerosis: the CLARITY (CLAdRIbine Tablets treating multiple sclerosis orallY) study. Mult Scler. 2011 May 1;17(5):578-93. https://doi. org/10.1177/1352458510391344

47. Brinkmann V, Billich A, Baumruker T, Heining P, Schmouder R, Francis G, et al. Fingolimod (FTY720): discovery and development of an oral drug to treat multiple sclerosis. Nat Rev Drug Discov. 2010 Nov;9(11):883-97. https://doi.org/10.1038/nrd3248

48. Cohen JA, Khatri B, Barkhof F, Comi G, Hartung H-P, Montalban $X$, et al. Long-term (up to 4.5 years) treatment with fingolimod in multiple sclerosis: results from the extension of the randomised TRANSFORMS study. J Neurol Neurosurg Psychiatry. 2016 May;87(5):468-75. https://doi.org/10.1136/jnnp-2015-310597

49. Fragoso YD, Adoni T, Gomes S, Gonçalves MVM, Parolin LF, Rosa G, et al. Severe Exacerbation of Multiple Sclerosis following withdrawal of fingolimod. Clin Drug Investig. 2019 Sep 1;39(9):909-13. https://doi. org/10.1007/s40261-019-00804-6

50. Diebold M, Sievers C, Bantug G, Sanderson N, Kappos L, Kuhle J, et al. Dimethyl fumarate influences innate and adaptive immunity in multiple sclerosis. J Autoimmun. $2018 \mathrm{Jan} ; 86: 39-50$. https://doi. org/10.1016/j.jaut.2017.09.009

51. Fernández Ó, Giovannoni G, Fox RJ, Gold R, Phillips JT, Potts J, et al. Efficacy and Safety of Delayed-release Dimethyl Fumarate for relapsing-remitting Multiple Sclerosis in prior interferon users: an integrated analysis of DEFINE and CONFIRM. Clin Ther. 2017 Aug 1;39(8):P1671-9. https://doi.org/10.1016/j.clinthera.2017.06.012

52. Blair HA. Dimethyl Fumarate: a review in relapsing-remitting MS. Drugs. 2019 Dec;79(18):1965-76. https://doi.org/10.1007/s40265019-01229-3

53. Bar-Or A, Pachner A, Menguy-Vacheron F, Kaplan J, Wiendl H. Teriflunomide and its mechanism of action in multiple sclerosis. Drugs. 2014 Apr;74(6):659-74. https://doi.org/10.1007/s40265-0140212-x

54. Scott LJ. Teriflunomide: a review in relapsing-remitting multiple sclerosis. Drugs. 2019 Jun 1;79(8):875-86. https://doi.org/10.1007/ s40265-019-01135-8

55. Miller AE. Oral teriflunomide in the treatment of relapsing forms of multiple sclerosis: clinical evidence and long-term experience. Ther Adv Neurol Disord. 2017 Dec 1;10(12):381-96. https://doi. org/10.1177/1756285617722500

56. Kieseier BC. The mechanism of action of interferon- $\beta$ in relapsing multiple sclerosis. CNS Drugs. 2011 Jun 1;25(6):491-502. https://doi. org/10.2165/11591110-000000000-00000

57. Bermel RA, Rudick RA. Interferon-beta treatment for multiple sclerosis. Neurotherapeutics. 2007 Oct;4(4):633-46. https://doi. org/10.1016/j.nurt.2007.07.001

58. Palé LA, Caballero JL, Buxareu BS, Serrano PS, Solà VP. Systematic review of depression in patients with multiple sclerosis and its relationship to interferon $\beta$ treatment. Mult Scler Relat Disord. 2017 Oct 1;17:P138-43. https://doi.org/10.1016/j.msard.2017.07.008
59. Hakkarainen KM, Juuti R, Burkill S, Geissbühler Y, Sabidó M, Popescu C, et al. Pregnancy outcomes after exposure to interferon beta: a register-based cohort study among women with MS in Finland and Sweden. Ther Adv Neurol Disord. 2020 Oct 7;13:1756286420951072. https://doi.org/10.1177/1756286420951072

60. McKeage K. Glatiramer Acetate $40 \mathrm{mg} / \mathrm{mL}$ in relapsing-remitting multiple sclerosis: a review. CNS Drugs. 2015 May;29(5):425-32. https://doi.org/10.1007/s40263-015-0245-z

61. Ziemssen T, Ashtamker N, Rubinchick S, Knappertz V, Comi G. Longterm safety and tolerability of glatiramer acetate $20 \mathrm{mg} / \mathrm{ml}$ in the treatment of relapsing forms of multiple sclerosis. Expert Opin Drug Saf. 2017 Feb;16(2):247-55. https://doi.org/10.1080/14740338.2017. 1274728

62. Ford C, Goodman AD, Johnson K, Kachuck N, Lindsay JW, Lisak R, et al. Continuous long-term immunomodulatory therapy in relapsing multiple sclerosis: results from the 15-year analysis of the US prospective open-label study of glatiramer acetate. Mult Scler. 2010 Mar 1;16(3):342-50. https://doi.org/10.1177/1352458509358088

63. Langer-Gould AM. Pregnancy and family planning in multiple sclerosis. Continuum (Minneap Minn). 2019 Jun;25(3):773-92. https:// doi.org/10.1212/CON.0000000000000745

64. Bayry J, Thirion M, Misra N, Thorenoor N, Delignat S, LacroixDesmazes $\mathrm{S}$, et al. Mechanisms of action of intravenous immunoglobulin in autoimmune and inflammatory diseases. Neurol Sci. 2003 Oct;24 Suppl 4:S217-21. https://doi.org/10.1007/s10072003-0081-7

65. Berger M. Adverse effects of IgG therapy. J Allergy Clin Immunol Pract. 2013 Nov-Dec;1(6):558-66. https://doi.org/10.1016/j.jaip.2013.09.012

66. Salameh JS, Deeb W, Burawski L, Wright S, Souayah N. Safety and efficacy of subcutaneous immunoglobulin in the treatment of neuromuscular disorders. J Clin Neuromuscul Dis. 2016 Mar;17(3):110-9. https://doi.org/10.1097/CND.0000000000000105

67. Lemaire A, Parquet N, Galicier L, Boutboul D, Bertinchamp R, Malphettes M, et al. Plasma exchange in the intensive care unit: technical aspects and complications. J Clin Apher. 2017 Dec;32(6):405-12. https://doi.org/10.1002/jca.21529

68. Pham HP, Staley EM, Schwartz J. Therapeutic plasma exchange - a brief review of indications, urgency, schedule, and technical aspects. Transfus Apher Sci. 2019 Jun 1;58(3):P237-46. https://doi. org/10.1016/j.transci.2019.04.006

69. Osman C, Jennings R, El-Ghariani K, Pinto A. Plasma exchange in neurological disease. Pract Neurol. 2020 Apr;20(2):92-9. https://doi. org/10.1136/practneurol-2019-002336

70. Pourcher V. Can patients on methotrexate receive live vaccines? Joint Bone Spine. 2019 Jul;86(4):415-7. https://doi.org/10.1016/j. jbspin.2018.12.008

71. SBIm. Calendário de vacinação pacientes especiais 2019-2020. Sociedade Brasileira de Imunizações; 2019.

72. Bühler S, Eperon G, Ribi C, Kyburz D, van Gompel F, Visser LG, et al. Vaccination recommendations for adult patients with autoimmune inflammatory rheumatic diseases. Swiss Med Wkly. $2015 \mathrm{Jul}$ 28;145:w14159. https://doi.org/10.4414/smw.2015.14159

73. Rubin LG, Levin MJ, Ljungman P, Davies EG, Avery R, Tomblyn M, et al. 2013 IDSA clinical practice guideline for vaccination of the immunocompromised host. Clin Infect Dis. 2014 Feb 1;58(3):309-18. https://doi.org/10.1093/cid/cit816

74. Park JW, Curtis JR, Moon J, Song YW, Kim S, Lee EB. Prophylactic effect of trimethoprim-sulfamethoxazole for pneumocystis pneumonia in patients with rheumatic diseases exposed to prolonged high-dose glucocorticoids. Ann Rheum Dis. 2018 May;77(5):644-49. https://doi.org/10.1136/annrheumdis-2017-211796

75. Rahier JF, Ben-Horin S, Chowers Y, Conlon C, de Munter P, D'Haens $G$, et al. European evidence-based Consensus on the prevention, diagnosis and management of opportunistic infections in inflammatory bowel disease. J Crohns Colitis. 2009 Jun 1;3(2):47-91. https://doi.org/10.1016/j.crohns.2009.02.010 
76. Pitsiou GG, Kioumis IP. Pneumococcal vaccination in adults: does it really work? Respir Med. 2011 Dec 1;105(12):P1776-83. https://doi. org/10.1016/j.rmed.2011.07.008

77. Horsburgh Jr CR, Rubin EJ. Clinical practice. Latent tuberculosis infection in the United States. N Engl J Med. $2011 \mathrm{Apr}$ 14;364(15):1441-8. https://doi.org/10.1056/NEJMcp1005750

78. Lok ASF, McMahon BJ. Chronic hepatitis B: update 2009. Hepatology. 2009 Sep;50(3):661-2. https://doi.org/10.1002/hep.23190

79. Natário A, Matias P, Weigert A. An update on immunosuppression for the HIV-positive kidney transplant recipient. Port J Nephrol Hypertens. 2012;26(2):139-47.

80. Salmon-Ceron D, Tubach F, Lortholary O, Chosidow O, Bretagne S, Nicolas N, et al. Drug-specific risk of non-tuberculosis opportunistic infections in patients receiving anti-TNF therapy reported to the 3-year prospective French RATIO registry. Ann Rheum Dis. 2011 Apr;70(4):616-23. https://doi.org/10.1136/ard.2010.137422

81. Mohseni M, Boniface MP, Graham C. Mononucleosis. In: StatPearls [Internet]. Treasure Island (FL): StatPearls Publishing; 2021. [cited 2020 August 15]. Available from: http://www.ncbi.nlm.nih.gov/ pubmed/29261868

82. Sari I, Birlik M, Akar S, Onen F, Kargı A, Akkoc N. Atypical infectious mononucleosis in a patient receiving tumor necrosis factor alpha inhibitory treatment. Rheumatol Int. 2009 May;29(7):825-6. https:// doi.org/10.1007/s00296-008-0775-5

83. Heard I. Human papillomavirus, cancer and vaccination. Curr Opin HIV AIDS. 2011 Jul;6(4):297-302. https://doi.org/10.1097/ $\mathrm{COH} .0 \mathrm{b013e328347335d}$ 